\title{
Aligning Medical and Muslim Morality: An Islamic Bioethical Approach to Applying and Rationing Life Sustaining Ventilators in the COVID-19 Pandemic Era
}

\author{
Aasim I. Padela | ORCID: 0000-0003-4834-2889 \\ Corresponding author \\ Department of Emergency Medicine, Medical College of Wisconsin, \\ Milwaukee, WI, USA \\ apadela@mcw.edu
}

Mansur Ali | ORCID: 0000-0002-3176-4746

Centre for the Study of Islam in the UK, School of History, Archaeology and Religion, Cardiff University, Cardiff, UK

alimmı@cardiff.ac.uk

\author{
Asim Yusuf \\ British Board of Scholars and Imams, Dundee, Scotland, UK \\ asimyusuf@hotmail.com
}

\begin{abstract}
The COVID-19 pandemic has spurred policymakers and religious leaders to revisit age-old questions about the ethics of pandemic control, the just allocation of scarce resources, and preparing for death. We add to these conversations by discussing the use of mechanical ventilation for Covid-19 patients. Specifically, we address the following: For Muslim patients/families when is it permissible to forgo mechanical ventilation? For Muslim clinicians, what circumstances justify the withholding or withdrawing of mechanical ventilation from patients? And for policymakers, is there an Islamically-justifiable rubric for allocating mechanical ventilation to patients in times of scarcity? Our Islamic bioethical analyses connect biostatistical data and social contexts with ethico-legal constructs to bridge the epistemic theories of biomedicine and the Islamic legal tradition. They reveal that forgoing mechanical ventilation is permissible for Muslims, that there are several conditions that allow for Muslim clinicians


to justify withholding and withdrawing mechanical ventilation, and also several policy rubrics for ventilator allocation that would be justifiable.

\section{Keywords}

SARS-CoV-2 - medical ethics - epistemology - crisis standards of care - fatwa - muftī maqāṣid - maṣlaḥa

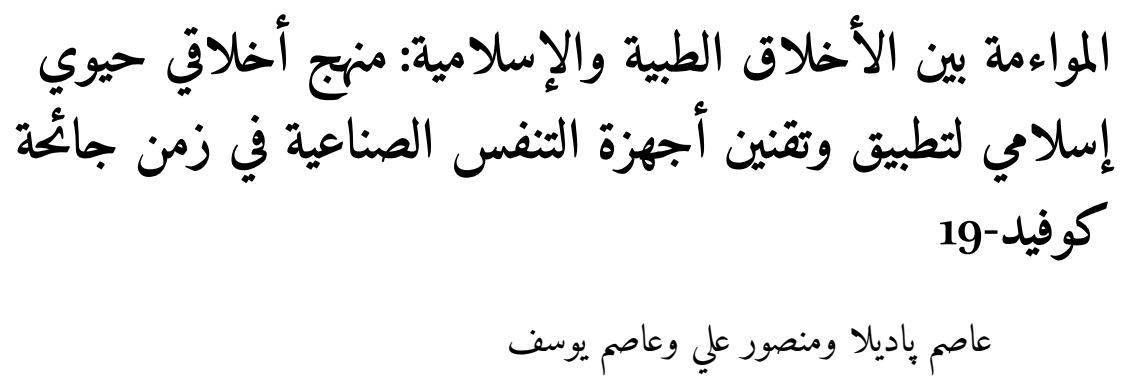

دفعت جائحة كوفيد-19 صناع السياسات والقادة الدينيين إلى إعادة النظر في المسألة الأزلية حول

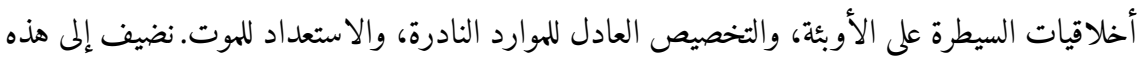

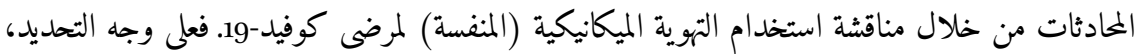

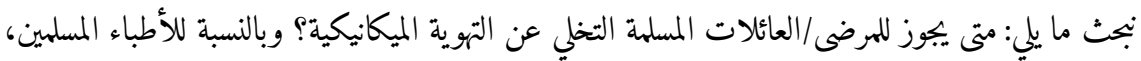

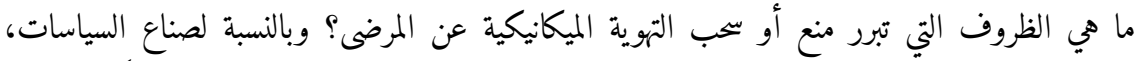

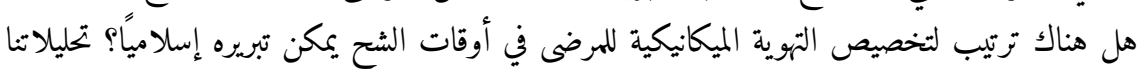

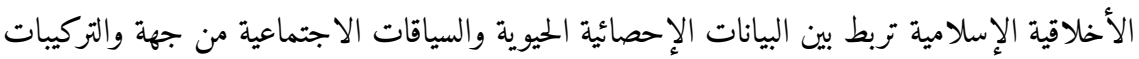

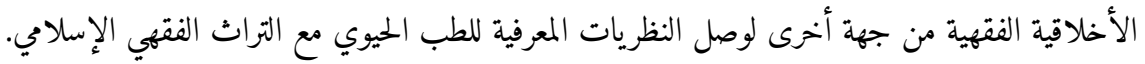

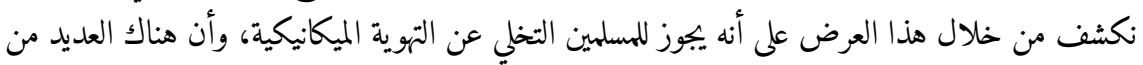

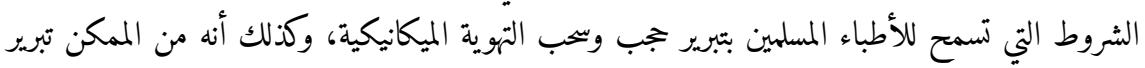

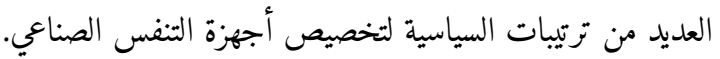




$$
\begin{aligned}
& \text { الكلمات المفتاحية } \\
& \text { سارس-كوفيد-2 - أخلاقيات الطبية - نظرية المعرفة - مؤشرات الرعاية خلال الأزمات - الفتوى - } \\
& \text { المفتي - المقاصد - المصلة - كوفيد }
\end{aligned}
$$

\section{1 \\ Introduction}

Shortly after the year 2020 was rung in, the COVID-19 virus spread beyond China to become a global health issue. Months on, the prevailing questions occupying political minds and healthcare leaders are largely the same: What is the best way to keep disease rates low? How do we allocate and manage available healthcare resources? How do we safely allow people to work, learn, worship and play? Different socioeconomic and political contexts have spurred diverse responses to these questions, and in turn the health and economic burdens of the disease vary considerably across national boundaries (Macon-Cooney et al. 2020; Center for Systems Science and Engineering 2020). This paper presents a normative Islamic perspective ${ }^{1}$ on the use of mechanical ventilation upon COVID-19 patients at different registers. At the micro-level, we deliberate on the moral position of forgoing artificial ventilation and related Covid-19 therapies from the perspective of Muslim patients, providers and policymakers. At the meso-level, we connect biostatistical data and social considerations with Islamic ethico-legal constructs thus joining the epistemic theories of biomedicine and the Islamic legal tradition. We contend that such fusion is critical for the developing field of Islamic bioethics. Lastly, we comment on the widermacro issues the example of forgoing ventilation and related therapies raises with regards to the craft of fatwa -making and deliberations of Islamic legists.

The special volume on Islamic Ethics of Pandemics and COVID-19 of which this article is a part, gathers pieces on the pandemic from normative-Islamic, as well as social-Muslim, perspectives. ${ }^{2}$ It attempts to bring theory and practice into dialogue, and in so doing illuminate meta-ethical and practical ethics frameworks. Such work is timely as there have been multitudes of fatwās and juridical opinions related to the pandemic authored by Islamic authorities around the globe (BMA 2020; Nuffield Council on Bioethics 2020; al-Khațīb 2020; Saleh and Ghaly 2020; AMJA Resident Fatwa Committee 2020b; BвSI

1 By this we mean a perspective rooted in the classical Sunnī ușūl al-figh frameworks.

2 By 'normative-Islamic' we mean an argument that is rooted in the Sunnī ușūl al-figh tradition. By 'social-Muslim' we mean the lived religious experiences of Muslims irrespective of reference to scripture. 
2020b; BinȚāhir 2020; al-'Anqāwī 2020). At times religious scholars have gone at it alone (Shabbir 2020), but more commonly Islamic jurists and Muslim clinicians have worked together to justify the shutting of mosques, altering burial practices, and suspending religious obligations such as Friday prayer and even Ramadan fasting (B BSI 2020a; AMJA Resident Fatwa Committee 2020a; IMANA Ethics Committee 202O; ECFR 202O; Maravia 2O2O; al-Ṣabrī 202O). More recently, engagements have been around whether Muslims should take the COVID-19 vaccines (B BSI 2020c; AMJA Resident Fatwa Committee 2020c; Wifaqul Ulama 2020; Darul Ifta, Darul Qasim 2020), and the implications of these fatwās on the authority structures and fatwā-making (Zulfiqar 2020).

As researchers analyze the Islamic bioethics discourse related to CoviD19, we wager that they will likely disagree about what Muslims ought to do or should have done, debate how Islamic bioethical deliberation was or should have been undertaken, and offer different takes on what Muslim polities did or are doing. Indeed, Islamic theology, according to the mușawwiba (correctionist) view, tells us that there can be no singular right 'Islamic' answer (al-Ghazāli 1993, 347; El Fadl 2003, 66). Additionally, observing social norms in different Muslim lands also leads to the conclusion that there is no unified Muslim practice (Anjum 2007; Geertz 1971). Recognizing this inherent plurality and multiplicity to Islamic/Muslim ethical discourse, we offer an Islamic moral perspective on three practical ethics questions related to COVID-19 and end-oflife care. Moreover, we model an approach to Islamic bioethical deliberation that aligns religious, biomedical, and social information.

Specifically, we will address the following three questions: At the Muslim patient-level, is it morally permissible to forgo mechanical ventilation and associated therapies when stricken with Covid-19? At the Muslim clinician/hospital-level, under what conditions is it morally justified to withhold mechanical ventilation and associated therapies from Covid-19 patients? And at the state policy-level, what is a justifiable rubric by which to allocate mechanical ventilation and associated therapies to patients in times of covid19 scarcity? We will address these questions by drawing on Sunnī uṣül al-figh frameworks. References to scriptural sources will be made to clarify concepts rather than to represent different hermeneutical possibilities, and biostatistical data related to mortality risk and therapeutic efficacy will be referenced to nuance ethical arguments.

Before attempting to answer the aforementioned questions, a few comments about our approach are in order. 


\subsection{Multilevel Analysis}

In scoping out the problem-space it is important to recognize that the COVID-19 pandemic involves a constellation of considerations that bring into relief ethical questions involving the public, patients, clinicians, and policymakers. This constellation involves (i) patient-level clinical care concerns over optimal and effective care for COVID-19 considering a specific patient's health status and comorbidities, (ii) healthcare system-level considerations about the infrastructure and resources needed to manage disease outbreaks and limit its morbidity and mortality, and (iii) social policy concerns focused on restructuring public spaces and economic programs in response to COVID-19 threat. Considerations at each of these levels are intimately connected to one another. For example, a bedside decision to apply or withhold ventilators is intimately connected to the existing supply of ventilators at a healthcare-system level, and both of these conditions result from policy-level decisions about social distancing and the device manufacture. While this example suggests a unidirectional upstream and downstream flow, in other words 'higher-level' societal decisions impact local challenges at the bedside, the reality is more complex. Illustratively, data from at the local level about scant community COVID-19 transmission may lead to the state level policies that remove economic incentives to manufacture ventilators, which may result in clinical decisions about ventilator use. Accordingly, the constellation of concerns is better viewed from a systems perspective with interconnections and multidirectional relationships (Elkins and Gorman 2014). In turn, a normative evaluation of the bioethics of COVID-19 must account for the ways in which the ethical questions at policy, provider, and patient levels relate to one another. Said another way, appropriately addressing questions requires multilevel analyses and a cogent meta-ethical framework that can be applied across the multiple levels.

\subsection{Using Biomedical Data to Inform shar'ì Rulings}

Employing scientific data (both social and natural) to service Islamic rulings is not to interject modern 'alien' epistemologies into sacred law-finding activities, rather it has precedent. For example, in his discussion of embryology through Islamic scriptures and Galenic medicine, Ghaly (2014) maintains that Islamic scholars were aware of, and employed, medical knowledge of the time

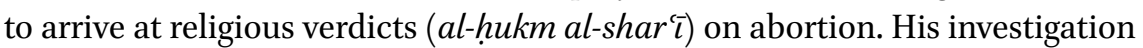
noted that medieval scholars such as Shihāb al-Dīn al-Qarāfì (d. 684/1285) and Ibn al-Qayyim al-Jawziyya (d. $75^{\circ} / 135^{\circ}$ ), as well as their modern counterparts, mitigated perceived tensions between the truth claims of scripture and of the natural sciences. They did so by either (i) metaphorically interpreting religious texts in order to accommodate medical views, or (ii) giving primacy to the religious sources and underscoring the inherent uncertainty of medical 
knowledge (Ghaly 2014, 57). The jurists' deliberations demonstrate that the deliverables of medicine were part and parcel of Islamic rule finding activities. Similar tensions between the natural sciences and scripture is noted by Stearns in his study of the bubonic plague and Islamic scholars' responses to it (Stearns 2008). Ibn al-Khațib (d. 776/1374) the vizier of Granada and a theologian wrote a scathing response to religious scholars denying contagion on the basis of Prophetic reports. He argued that the Prophetic reports had to succumb to the empirical evidence that proved human transmission of the plague. In contrast, his teacher Ibn Lubb (d. 782/1381) maintained the view extrapolated from Prophetic statements that diseases are not contagious and to believe otherwise was to assign causation to other than God. Again, we see classical scholars striving to incorporate, or alternatively marginalize, the truth claims of biomedicine.

While some classical jurists were able to indifferently disregard biomedical data, we hold that it is no longer tenable to overlook clinical knowledge, biostatistical data, and social scientific understandings when penning religious views on health behaviors or bioethical policy. While this may seem obvious, some scholars advise against relying on medical science for the purpose of a presumed greater good. For example, some contemporary scholars believe that organ transplantation technology is a cultural imposition upon Muslims and must be rejected despite its clinical merits (Ali and Maravia 2020, 8). Moreover, Islamic jurists often advocate that clinical medicine and physicians should defer to scripture and scholarly precedent when defining concepts, e.g. death, that have clinical, social, and religious dimensions (Stodolsky and Kholwadia 2021; Hamdy 2013).

\subsection{Resolving Truth Claims by Evaluating Epistemic Certainty}

So how is one to navigate between scripture and the natural or social sciences? While there have been tomes dedicated to this topic by classical jurists and theologians, most notably, by al-Ghazālì (d. 505/1111) (tangentially in his Tahāfut al-Falāsifa (200o) and more directly in Qanūn al-Ta'wīl (1993)), Ibn Rushd (d. 595/1198) (in his Faṣl al-Maqāl (1997)) and Ibn Taymiyya (d. 728/1328) (in his Dar' al-Ta'ärud (1991)), these of course made reference to what was considered science at the time - natural philosophy. Though each of these scholars reached different conclusions, the level of precision and certainty of modern science is arguably far beyond what they conceptualised. Thus, making direct reference to their works is a potentially misleading endeavour not germane to our cause. Rather, a more contemporary tie in - founded on the same epistemic principles evinced by these medieval figures - is found in an essay by 
Kamaluddin Ahmed. ${ }^{3}$ A basic description of Ahmed's typology of perceived conflict between the natural or social sciences and scriptural claims and how resolution is to be effected is provided below. At base, any form of knowledge is graded on a hierarchy from apodictic certainty $\left(q a t^{\dagger}\right)$ to speculative (wahm). Thereafter, potential conflict is dealt with as follows:

1. A matter can be purely scientific and one where scripture make no claims. For example, identifying the best form of massage to relieve tension from muscles. Since there is no competition with the Shari $a$ here, empirical findings will be treated as actionable, though probabilistically established, knowledge (zann).

2. Science makes a claim about something and scripture makes a contrasting claim. Both claims are probabilistic (zannī) and do not yield certain (yaqīni $)$ knowledge. For example, knowledge of neurology reveals that emotions are created in the brain whereas Islamic scripture asserts that the heart is the seat of emotions. Ahmad suggests that hermeneutical strategies that harmonize and reconcile between these different truth claims must be employed.

3. Science makes a claim which contradicts a clear unequivocal scriptural evidence ( $\left.q a t^{c} / y a q \bar{i} \bar{\imath}\right)$ for example the accounts given by both of the origins of the human species. Ahmed maintains that if science itself accepts that this claim is probabilistic, then scriptural knowledge will take preference. However, if the scientific knowledge is equally certain based on its own methodological principles, then for the likes of al-Ghazāli and Ibn Rushd such conflict is not rationally possible. Both advocate tweaking the truth claims of each science until the contradiction no longer remains (Ahmed 2021, 333-336). ${ }^{4}$

While Ahmed's typology does not detail the mechanics of resolving tensions, he asserts (and we agree) that natural and scientific theories can be plotted on the same epistemic gamut employed by Islamic scholars in order to classify sources of knowledge. These include 'certain knowledge' (yaqīnī) which yields full confidence in the knowledge imparted. This is followed by highly probable

3 Kamaluddin Ahmed is a seminary and university-trained Islamic studies expert. He holds advanced graduate degrees in Islamic Law and Jurisprudence with authorizations (ijāza) in the rendering legal opinions (iftä) and general Islamic scriptural sciences (Alimiyya) from seminaries in Pakistan including Jamia Ashrafia. Currently, he is a DPhil candidate in Oriental Studies at the University of Oxford examining the relationship between textual traditions and legal reasoning in the intellectual history of Islamic law.

4 For an example of the tension between the truth claims of science and religion and a mature reconciliation of the two, see (Yusuf 2017). 
knowledge' (ghalabat al-zann) where the scale is tilted towards confidence but not as strong as 'certain knowledge', and 'probable knowledge' (zann) when the scale is above $50 \%$ certitude. Most of Islamic law and Islamic bioethical deliberations operate in the probabilistic zone. The third category is doubt (shakk). This is when the degree of confidence is 50:50 and the scale is not tilted towards any one position. Highly uncertain (wahm or mawhüm) follows suit when the level of confidence is below $50 \%$.

Another way of looking at certainties is that with yaqin, no alternative view is possible; with ghalabat al-zann, alternative views are discounted; with zann, alternative views are considered but deemed less likely; with shakk, no judgment is possible (tawaqquf); and wahm can be ignored even in the absence of an alternative view. The implications of this classification of knowledge will become apparent later in the article.

Islamic verdicts on biomedicine often hinge on assessing benefit (mașlaha) and harm (mafsada) inherent to an action; where benefits outweigh harms judgements of ethico-legal permissibility are rendered, and the opposite for when harms outweigh benefits. In our view, however, neither harm nor benefit can be appropriately ascertained and specified without recourse to biomedical data. This melding of biomedical with the Islamic is epistemically valid. Indeed, reasoning exercises within figh validate the status of ratiocination, ' $a q l$, in both deriving values from the scriptural sources, as well as on furnishing views on the ethical in cases where the scriptural texts are not univocal. Similarly, Islamic law's recognition of human convention, 'urf, as a source of moral knowledge and as a grounding for ethical practice provides sufficient space for social and natural scientific data to be used in Islamic ethico-legal decision-making (Ahmed 2021). As Ahmed and others (Qureshi and Padela 2016) note a biostatistical approach to harm (darar) and fear (khawf) is a valid form of knowledge accumulation in the Sharĩa.

\subsection{Gaps between Islam and Muslims}

Finally, as we lay out our arguments we acknowledge that between the Islamic and Muslim, ${ }^{5}$ and theory and practice, there are wide gaps. Our ethico-legal analyses requires further nuancing to context before it is implemented by patients, providers, and policymakers confronting the COVID-19 pandemic.

5 By 'Islamic' we mean normative dictates found in texts, by 'Muslim' we mean the everyday lived experience. 


\section{Question 1: At the Muslim Patient-Level, Is It Morally Permissible to Forgo Mechanical Ventilation and Associated Therapies When Stricken with COVID-19?}

COVID-19 is a viral illness with significant respiratory manifestations. Individuals infected by the disease commonly develop a cough, shortness of breath and fever, and many lose their sense of smell and taste, muscle aches, and diarrhoea. There is a spectrum of disease from no symptoms, to mild common cold-type symptoms, and to overwhelming illness and death $\mathrm{Wu}$ and McGoogan 2020). Critical illness resulting from COVID-19 principally involves individuals struggling to breathe and oxygenate tissues. Given this challenge, the morality of applying mechanical ventilators along with ancillary treatments is a key issue.

To resolve an Islamic perspective on the matter, the first step is to consider the general ethico-legal stance on seeking clinical treatment. ${ }^{6}$ Classical Sunnī law, as espoused by the prevailing opinions within the four Sunnī schools determine seeking healthcare to be a permitted act (mubāhn) (Ghaly 2010; Al-Bar 2007). Importantly it is not an obligation, meaning that moral censure is not attributed to the individual who forgoes medical treatment. This view is espoused by scholars such as Ibn Taymiyya and al-Ghazālī, and is recorded within the classical legal works of all four schools (Padela and Qureshi 2017). Detailing the scriptural and legal reasoning undergirding these rulings is beyond the scope of this paper. Suffice it to say, however, that an ontology/theology of illness and cure residing with God as noted in the Qurān and hadìth, and practices of the early community were reconciled to furnish these views. Contemporary thinkers note that these views must be cautiously implemented given that medical treatment differs greatly today from when these opinions were advanced (Ghaly 2010). Notably, healthcare is much more efficacious today than it was fifty years ago, and most definitely is more effective than it was a millennia ago.

At the same time, some classical scholars, as well as contemporary Islamic authorities, delineate conditions under which seeking medical treatment becomes obligatory. This evaluation turns on the notion of treatment efficacy and life threat. Where therapies are known to remove illness-related harms, meaning that there is certainty (yaqin) or near certainty (ghalabat al-zann) of such, and the harm to be avoided is death, jurists lean towards there being an obligation to obtain that treatment (Padela and Qureshi 2017; Padela and

6 See (al-Qaradāghī and Muhammadī 2006, 187-201) and (al-Shinqīṭi 1994) for an exhaustive discussion on this. 
Mohiuddin 2015). Contemporary discussions further expand the zone of obligation. In 1992 the International Islamic Fiqh Academy (OIC-IIFA), an affiliate of the Jeddah based Organization of Islamic Conference (OIC) which includes Sunnī jurists from all four schools of Islamic law as well as Shia jurists, revisited the classical views. In accounting for modern-day treatment efficacy they declared that seeking medical care is obligatory when neglecting treatment may result in (1) the person's death, (2) loss of an organ or disability, or (3) if the illness is contagious and a harm to others (OIC-IIFA 2000).

These classical and contemporary perspectives are relevant to the ethicolegal status of ventilator assistance for COVID-19 patients as they setup thresholds for making ventilation assistance obligatory. The first threshold condition is whether such assistance is surely life-saving, and second is to consider whether not obtaining treatment harms others.

\subsection{Is a Ventilator along with Ancillary Therapies When Applied to covid-19 Patients Life-Saving?}

As noted above, severe COVID-19 disease leads to respiratory problems and for some respiratory failure. In cases of primary respiratory failure there are but a few clinical therapies to stave off death: non-invasive or invasive assisted ventilation. Non-invasive methods involve using machines that deliver positive pressure and oxygen to the lungs to assist with ventilation while the patient is awake. These technologies do not enter the patient's body cavity, e.g. respiratory tract, and are externally applied. Invasive ventilation, on the other hand, requires the insertion of an apparatus into the oral cavity of a patient (a respiratory tube) so that positive pressure and oxygen can be delivered and requires the patient be unconscious. In common vernacular this latter type is called intubation and being placed on a 'breathing machine' Intubation is a risky procedure in that it is not always successful and patients can die from its complications. In the context of COVID-19 it also increases risk of disease transmission to staff involved (Yao et al. 2020; Brown III et al. 2015).

A minority of CoviD-19 patients suffer from respiratory failure to such an extent that they need non-invasive or invasive ventilatory assistance, but when they do the prognosis is generally poor. Given that CoviD-19 is a novel disease, studies on its natural course and mortality are ongoing. Yet the available global data suggests that less than one half of individuals with Covid-19 who require intubation can be weaned off the therapy and survive to discharge (Ñamendys-Silva 2020). For example, in a clinical case series of approximately 300 COVID-19 patients presented to two hospitals in Manhattan between March and April, 33\% of COVID-19 patients required mechanical ventilation, and only $33 \%$ were able to be weaned off this therapy and breathe successfully 
on their own (Goyal et al. 2020). Data from the US state of Georgia echoes these findings with $33 \%$ of individuals requiring intubation dying (Auld et al. 2020). A larger case series of over 5700 patients from around New York City revealed that over $20 \%$ required mechanical ventilation, of which $25 \%$ died and only $3 \%$ were discharged alive (Richardson et al. 2020). Many of these studies can be considered 'incomplete' in the sense that a large proportion of patients remained on ventilator support at the time of publication without having died or been extubated, hence the full mortality rates remain to be ascertained. Nonetheless international data fills in some gaps as a Chinese case series from Wuhan noted that over 90\% of individuals who required mechanical ventilation died (YLiu 2020), while Italian data from Milan and Lombardy found that about a quarter of patients requiring mechanical ventilation died (Zangrillo et al. 2020). It bears mention that these data come from healthcare systems with robust capacity to care for patients in intensive care units and with sufficient mechanical ventilators. Mortality in regions without such technical capacity is expected to be much worse. For our purposes, these data support the idea that mechanical ventilation is not a certain cure; only a minority of patients on whom it is applied survive to discharge and a great number require continued intubation for an unknown and prolonged time period. This latter fact compounds societal resource scarcity and leads to its own health risks.

Consequently, ventilation assistance is life-saving for only a minority of patients. Said another way there is no certainty, and the probability is not high, that intubation will save the life of a covid-19 patient, either because the respiratory failure does not respond to this therapy or because the illness effects other organs and bodily functions which are unresponsive to remedies. As research continues, we may be able to predict which patients will benefit from invasive ventilation and which will not. However, at present and for all comers, Islamic scholars must grade the therapy as doubtful (mawhüm) to bring about benefit and resolve its moral status accordingly.

\subsection{Is Not Being Treated for COVID-19 a Credible Harm to Others?}

The threshold set by the OIC-IIFA that the lack of treatment to be a credible harm to others is somewhat difficult to resolve in the context of a CoviD-19 patient with respiratory failure. Firstly, there is no known treatment for the disease. Hydroxychloroquine and other purported 'cures' have not proven to be effective cures, though some medications may reduce the duration of disease (Geleris et al. 2020; Magagnoli et al. 2020). Given the lack of a clinical cure, the public health focus has been on reducing the transmission of the disease by implementing social distancing measures, masking protocols, and curtailing 
aspects of public life. In a narrow sense such measures are not cures, but in the context of public health and social medicine, these preventive measures curtail risk of individuals becoming infected.

Secondly, applying the metric of credible harm from a CoviD-19 patient with respiratory failure not being treated is difficult. Even if we take the view that public health measures are treatments, these are not readily applicable to the patient with respiratory failure. Certainly, the patient can be masked but social distancing is not appropriate in the clinical environment where the patient is in need of urgent medical treatment. Masking is an effective means of reducing disease transmission and thus can be morally sanctioned. However, the clinical treatments, invasive and non-invasive ventilation, do not prevent harms to others. Rather, these treatments increase the risk of disease transmission to bystanders and clinical professionals. The reason for this increased risk is that COVID-19 spreads primarily through respiratory droplets, and when positive pressure is applied these can be aerosolized and broadcast into the ambient air in the patient's room. Non-invasive treatments such as continuous positive pressure ventilation (CPAP) continuously aerosolize droplets into the surrounding air, while intubation reduces such transmission since the respiratory circuit is a closed system (the tube in the lungs connects to a machine). Nonetheless, the process of intubation aerosolizes droplets and in so doing attributes disease risk to the personnel involved in the procedure. While the relative risk of disease transmission is modest, it is not negligible and thus a potential harm to treating clinicians and staff (Brewster et al. 2020; Yong and Chen 2020). Forgoing therapy also increases risk to others as respiratory droplets from the infected patient are spread in the community, and airborne as well as fomite transmission may also occur to close contacts. In order to weigh which action conveys greater harm to others, we must also appreciate the time factor. Intubation is generally a short procedure and droplets are contained within the circuit once the patient's lungs are connected to the machine via an endotracheal tube. However, a patient who is suffering from respiratory failure also does not have long to live as the patient will likely die within minutes or hours if he/she is not provided ventilation support. At death droplet production would cease.

In consideration of the above, a patient with COVID-19 suffering from respiratory failure, is in complex moral conundrum. There is no definitive therapy given that survival is less than $50 \%$ even if intubated and placed on a ventilator. Additionally, applying such therapies increases the risk of CoviD-19 transmission to healthcare professionals involved with intubation and post-intubation care. At the same time, forgoing therapy conveys risk of transmission of the disease to others and the patient would die. Yet it would seem odd, from an 
Islamic moral perspective or otherwise, to suggest that all CoviD-19 patients with respiratory failure be intubated and quarantined so that disease transmission risk is mitigated. For one intubation and ventilation is not certainly beneficial to the patient and may indeed harm the patient given the risks of ventilator-associated pneumonia, bed sores, and other nosocomial infections that hospitalization in an ICU carries (Koulenti, Tsigou, and Rello 2017; Manley 1978). Secondly there are resource issues to consider. There simply are not enough hospital beds, ventilators, and support staff to make such a policy actionable. We will take up this point in the next section, but it is worth underscoring the connection between the moral evaluation of individual patient care and society-level resources.

Although the moral calculus of risk-benefit is hard to quantify accurately, and is multifactorial, the forgoing suggests that it is morally permissible for a Muslim patient to forgo mechanical ventilation and associated therapies when stricken with COVID-19 because these do not assuredly benefit him or her. Secondary considerations about which state, a non-intubated patient with respiratory failure at home or in the hospital, or an intubated patient in the hospital, is less harming to others is not clear. The data on risk is not readily available, and the category of harms expands beyond biological to encompass social, psychological and ethical harms. We hazard that forgoing treatment would remain permissible because of this ambiguity. ${ }^{7}$

\section{Question 2: Clinician-Level: Under What Conditions (Both Societal and Patient-Level) Is It Morally Justified to Withhold Mechanical Ventilation and Associated Therapies from covid-19 Patients?}

Clinicians have a privileged position in Islamic moral theology as they are charged with preserving one of the overarching objectives of the Sharita: life (nafs). Al-Shāfíi (d. 204/820) mentions that there are two professions of people who are indispensable to the community. They are the 'ulam $\bar{a}^{3}$ whose duty extends to the preservation of religion (din) and who tend to the spiritual welfare of the community, and physicians who are charged with attending to the community's physical wellbeing and preserve individual life (cited in al-Bārr and Shamsī-Bāshā 2004). Similarly, 'Izz al-Dīn ibn 'Abd al-Salām (d. 66o/1262) finds that the practice of medicine and of Islamic law are similar is that they both seek to maximize benefit and reduce harm (cited in al-Bārr and Shamsī-Bāshā 2004, 7). Before answering the question, 'Under what

7 See (ввSI 2020b) for an example. 
conditions is it morally justified for clinicians to withhold mechanical ventilation and associated therapies from CoviD-19 patients?', we preface the answer with some general Islamic principles related to the ethics of a Muslim physician. These broad principles will assist in conceptualizing a nuanced answer.

A Muslim physician is duty-bound to restore health and save lives so long as she remains faithful to the dictates of the Sharîa related to her craft. Some of these conditions relate to the doctor's ability to practice, whilst others relate to how the doctor practices her profession. The most obvious of these is the competency of the doctor to practice medicine. This is adjudicated today by the plethora of certifications and licenses that practicing medicine requires. However, during the Prophet's era there was no such guild as charlatans, pseudo-physicians and mendicant doctors were prevalent. Thus, it is reported in a hadith that the Prophet said, "Whoever practices medicine without learning is liable" (al-Tirmidhī 1996).

Aside from practicing within her zone of competency to preserve human life, the moral ethos of a physician, at least theologically, requires that she recognize that health and illness are part of God's sapiential plan. Moreover, she must reflect that a human's life is 'owned' by God and a fair usage policy applies when seeking to restore or enhance human health (al-Bukhārī 1997; Ali 2019). Implicitly then humans do not have the right to forgo living as this life does not belong to them. Hence the preservation of life is an absolute principle which cannot be violated due to secondary attributes (such as age, health, social status etc.). This idea is based on the Qur'annic verse, "On account of [his deed], We decreed to the Children of Israel that if anyone kills a person - unless in retribution for murder or spreading corruption in the land - it is as if he kills all mankind, while if any saves a life it is as if he saves the lives of all mankind" (Q 5:32).

Another Shari'a principle related to the profession of medicine is that of equity, as in a physician will should not privilege one patient over another without valid and justifiable rationale (some of which are discussed below). Finally, the principal duty of physician is to ward off harm and maximize benefit as gleaned from legal maxims such as deflecting harm takes precedence over procuring benefit (dar' al-mafāsid awlā min jalb al-mașāliḥ) and a personal harm is tolerated in order to deflect a public harm (yutahammal al-darar al-khāṣṣ li-ajl daf' al-ḍarar al-āmm) (Ibn Nujaym 1999, 74, 78). One may incorrectly surmise from these legal maxims that Islam is utilitarian in its outlook and that a benefit (mașlaha) driven approach to the Sharía is consequentialist in nature. This is not accurate (Kenney and Moosa 2014). ${ }^{8}$ Islam is an eclectic

8 See (al-Būṭ̂̄ 1973) for a critique of the unbridled use of mașlaḥa in Islamic law. 
blend of deontological moral imperatives (such as the absolute sacredness of life) tempered by consequentialist (mașlaḥa-oriented) precepts. For example, if two people are competing for the same medical resource and by allocating it to the one who is in dire necessity (certain death without the intervention), the deprived patient experiences excruciating, but not life-threatening, pain, this is to be tolerated as the sanctity of life itself over-rides all other considerations. This is enshrined in the legal maxim, 'when there is a competition between two harms, the least damaging is to be privileged' (idhā ta'ärada mafsadatān rū'iya a'zamuhumā dararan bi-irtikāb akhaffihimā) (Ibn Nujaym 1999, 76; al-Sarīī 2020)

These are broad principles that the physician must follow. However, beyond these general conditions, are there other ethical norms that the physician needs to abide by? The polymath scholar al-Suyūtị (d. 911/1505) mentions that if something is not clearly mentioned in scripture, and the language does not accommodate it, one can resort to common practice ('urf) to decide on the matter (cited in al-Bārr and Shamsī-Bāshā 2004). By way of example, God says in the Qur'ān that humans are dignified (Q 17:70). However, the actualization of this dignity is not spelled out in the Qurān or by Prophetic practice. Hence it is left largely to the society to decide how dignity is to be defined (Butt 2019, 40; Raḥmānī 2010, 48). Based on this principle, Rabī b. Sulaymān (d. 270/870) quotes al-Shāfīi saying,

If someone asks another to let his blood, or to circumcise his son, or to treat his horse, as a result of which loss occurred then the situation is as follows: if the person did what is done by the people in the trade in such circumstances which is considered beneficial then there is no liability. But if his performance was at variance with what is the customary practice, then he is liable.

cited in YACOUB 2001, 131

These sources provide religious justification for the autonomy professional guilds have in managing their affairs according to the standards they have developed. Limits exist as general Sharía norms cannot be violated by custom and convention, but a measure of deference is given to professional practices and standards.

Harking back to the question above given that the mechanical ventilation is not uniformly life-saving, a patient/family is justified in forgoing the treatment. Correspondingly, since ventilation is not obligatory upon the patient/ family, it is not obligatory for a Muslim physician to apply it either. Medical convention demands that a physician not act to apply the treatment against 
a patient's will. Indeed, such an act reeks of objectionable paternalism where the patient's values are neglected during the course of furthering clinicians' interests, and is deemed reprehensible by prevailing medical ethics (Häyry 2002; Buchanan 1978). It also runs counter to secular law where a physician could technically be charged with assault and battery, and it also contravenes Islamic views on not perpetrating harm upon others (Al-Bar 2005). For the clinician, decisions taken on the patient's behalf fall under the ethics of safeguarding trusts (amāna) (BвSI 2O2Ob). This is enshrined in the Qurānic command, "God commands you to faithfully bring forth to their owners that which has been entrusted to you, and that when you decide between people, to do so justly. How excellent is what God exhorts you to! God is All-Hearing and all-Seeing" (Q 4:58). A clinician found to be in breach of this trust is morally culpable.

In the context of societal scarcity, where clinicians are charged with withdrawing or withholding life-support apparatus, a nuanced approach is demanded. First and foremost, we must recognize that Muslim clinicians work in different legal contexts. In some areas the pandemic has led to a context where 'crisis standards of care' are applied and there is a shift in focus from patient-centered practice to public-focused considerations (American Nurses Association 2020). In this context, a Muslim clinician is morally obligated to follow the law of the land as well as her professional guild's conventions in so far as is possible and the action does not violate a higher Islamic mandate. Hence, she would be permitted to withhold or withdraw ventilatory treatment from a patient with the resource is scarce and the law and medical practice align. Justification for honoring contracts is found in Muslim scripture. The Qur'an says, "You who believe, fulfil your obligations" (Q 5:1). In another place describing those who are pious, it reads, "Who keep pledges whenever they make them" (Q 2:177). The above teachings are captured in the practices of the Prophet where he is reported to have emphasized that, "Muslims are bound by their contracts" (Abū Dāwūd 1998). ${ }^{9}$

Furthermore, in cases where the Sharita is silent, one of the ways that Islamic scholars gauge God's approval is by conducting a risk-benefit analysis. The contemporary scholar 'Ārif al-Qaradāghī provides a formula for knowing whether God sanctions an action or not. Al-Qaradāghī argues that God is pure goodness and will only sanction that which is for the betterment of people. If by comparing the harm and benefit of an action, the net harm is greater than its benefit, then God's consent ceases to exist in that thing, and it is deemed

9 Bābfial-șulh. 
to be prohibited. However, if the net benefit preponderates the harm, then it can be assumed that God is happy to sanction this action (al-Qaradāghì 2011, 55). Since we have already established that the efficacy of treatment in the case of a patient who has been mechanically ventilated is doubtful (mawhüm) and that there is an imminent health risk to clinical professionals pre- and post-intubation, it is Islamically justified for clinicians to withhold or withdraw such treatment. Some scholars have argued that if the probability for recovery is low for a patient (based on clinical algorithms and biostatistical data), one can argue that medical intervention disrupts the inviolability (hurma) and dignity (karāma) of the patient and thus the harms outweigh the benefits (BBSI 2O2Ob).

Question 3: At a State Policy-Level, What Is a Justifiable Rubric by Which to Allocate Mechanical Ventilation and Associated Therapies to Patients in Times of CoviD-19 Related Scarcity?

Following on from the fact that CoviD-19 can lead to severe respiratory distress is that some patients will require ventilator support. As discussed in the preceding sections, for some this support will be life-saving but for many it will not be. Forecasting who will benefit most from mechanical ventilation is will challenging given the 'newness' of the disease. Expert clinicians are still seeking out the most effective ventilator management protocols for patients with COVID-19, and researchers continue to mine clinical data to determine which patient characteristics portend good outcomes from such therapies (Marini and Gattinoni 2020; Tobin 2020).

When these uncertainties are coupled with the moral duties of rescue and to restore health surrounding the medical profession, it seems appropriate for frontline clinicians to provide ventilator support to patients in need. Yet doing so for all-comers would quickly deplete the supply of mechanical ventilators and its instruments, intensive care beds, respiratory technicians, sedative medications and the like in any given locale. No country in the world has sufficient supply of mechanical ventilators and ancillary instruments needed to meet the demand should the disease become widespread. Leading health policy research think-tanks around the globe have modelled the supply and demand curves based on different rates of disease spread to demonstrate this fact (Institute for Health Metrics and Evaluation 2020). Such depletion would mean that future patients could not obtain the therapy until a ventilator becomes available either through death of the previous patient or their will recovery. 
Policy makers around the globe have sought to avoid this catastrophic scenario by incentivizing the production of ventilators, installing quarantine policies to reduce the transmission of the disease, and enforcing various forms of lockdown and stay-at-home orders to further forestall coviD-19 spread. In some countries such as New Zealand and Taiwan, disease transmission has abated and no crisis looms. In others, such as the United States and Brazil, COVID-19 infectivity in on the rise and a looming crisis where health needs outstrip medical supply appears on the horizon (Institute for Health Metrics and Evaluation 2020). The term 'crisis standards of care' is used within the medical ethics literature to describe policies that adjust norms of healthcare delivery in light of extreme resource scarcity (Viswanathan et al. 2012). These scenarios are different from mass casualty and natural disaster incidents where triage protocols are implemented because the expected duration of the crisis is longer, and the societal impact is more widespread (Mareiniss 2020). The global pandemic has spurred sessions around ethically robust crisis standards of care addressing the question of ventilator allocation (White and Lo 2020). With respect to such allocation, we consider will what sort of rubric would be justified from an Islamic moral standpoint?

It bears mention that the decision to allocate mechanical ventilation to some patients means that others will not obtain this critical resource, or will have it removed. Said another way, resource allocation policies at the statelevel will entail decisions about withholding and withdrawing ventilators at the bedside. Decisions made by state authorities, hospital administrators and ethicists will be implemented by clinicians on the front lines and impact patients at the ground-level. Consequently, a holistic ethical assessment must account for the moral choices faced by these agents as well.

The foundational premise of Islamic ethico-legal evaluation is that deflecting harms takes precedence over the procuring of benefits (dar' al-mafäsid awlā min jalb al-mașāliḥ) (Ibn Nujaym 1999, 78). Accordingly, in the CovID-19 context, the ethical grounds for policymaking rests on the idea that these policies deflect disease-related harms from individuals. When it comes to social policies around masking and restrictions on public gatherings, the reduction of harm is probable and evidence-based (Chu et al. 2020). However, with respect to allocating ventilators at times of scarcity, harms may accrue the course of pursuing benefit. Recall that crisis standards of care are enacted when scarcity of resources is real; the numbers of patients needing ventilators and accompanying resources outstrips supply. In seeking to benefit one patient, the opportunity cost is helping another; someone potentially gains and someone definitely loses out on that gain. The question is whether, and what type of, harm accrues in various scenarios. 
In the case where two patients require intubation and resources are available such that only one can be intubated [Scenario A], one can argue that no one is harmed. Rather the physician (and the policy which dictates which patient gets intubated) seeks to procure a potential benefit for one patient, while the other patient is not deliberately (nor actively) harmed by such an action. In Islamic parlance a moral duty to rescue never existed for this latter patient because there was no capacity to save. Indeed, this argument is advanced by the contemporary Moroccan scholar Mawlūd al-Sarīī (202O). Using a paradigm case of a person and the obligated daily prayers, al-Sarīin makes the following analogy. He reasons that a healthy adult Muslim is required to pray when the prayer time arrives but is not responsible to pray when the time of prayer has not yet arrived. Thus, a doctor who has already triaged a patient to a ventilator is akin to a person praying when the time of prayer has just come in; he is not responsible for the next prayer (or patient) until that time (or patient) arrives. However, when the next prayer time (or patient) arrives the moral obligations that ensue must be judged in accordance with the capacity to perform them.

However, in the case where that mechanical ventilation must be removed from one patient in order to apply it to another [Scenario B], then a harm accrues in order to procure a potential benefit. The patient who has the ventilator withdrawn will surely be harmed as her chance at survival will be reduced by this action. At the same time, the patient suffering from respiratory failure has their chances of survival increased. If the cardinal maxim is to be followed, then this second scenario is morally objectionable as the deflecting of harm must be prioritized over procuring benefit, and this view gains support by the fact that the harm is certain while the benefit is uncertain. It also aligns with the Prophet's statement that there is no harm or harming in Islam (Ibn Māja 1998, 72; Ibn Nujaym 1999). ${ }^{10}$ Moreover, an argument that this scenario involves the coming together of two harms and the lesser must be committed to avoid the greater is specious because the two harms are not coexistent in time; both patients have not arrived concurrently. Generally speaking then, in Scenario B a Muslim clinician would be morally obligated to deflect harms from the intubated patient and not remove a ventilator to privilege another patient either in the present or the future. In jurisdictions where such is possible, a claim of conscience can be made. Claims of conscience are supported by the Prophet statement "leave that which disturbs your heart for that which brings it solace" (al-Tirmidhī 1996). ${ }^{11}$

\footnotetext{
10 Bāb man banā fì haqqih mā yaḍurru bi-jārih.

11 Abwāb șifat al-qiyāma wa-l-raqā̄iq wa-l-wara', bāb 125.
} 
Yet, a critical nuance may morally justify the withdrawing of ventilation and life support in Scenario B. Given that mechanical ventilation is not life-saving or curative in the majority of COVID-19 cases, one may argue that the therapy is doubtful and coexists with known harms of being in the hospital, sedated, bed-bound, and the like. Potential harms of ventilator-associated pneumonia and other infections are also anticipated. Classifying the treatment as a harm would allow one to argue that the act of withdrawing life support and ventilation is an act of beneficence, particularly when the patient has not improved by means of such therapy after several days. Once this harm is removed and a ventilator becomes available, the oncoming patient in respiratory distress can opt to accept the harm of ventilator assistance in the hopes of procuring a potential life-saving benefit. The Muslim physician as a moral agent can choose to apply this doubtful therapy out of a duty to rescue, or can claim conscience grounding this view in the Islamic mandate to not harm and the Hippocratic ideal of Primum non Nocera. From a physician perspective, physician actions in scenario B can be justified, Islamically, either way. But our concern is with the overall policy.

Bolstering an argument against a policy mandating ventilator withdrawal in scenario B is that privileging those who are closest or come first to utilize the scarce resource has religious backing. Scriptural grounds for privileging those who come first are derived from Prophetic guidance such as, "A person must not make another person stand up from his place in order to sit in it himself" (al-Bukhārī [n.d.]). ${ }^{12}$ Furthermore, the Prophet's declining an offer that a designated resting area be made for him - despite his exalted status as a Prophet and lawgiver - in the town of Mina by noting that "Mina is the resting place for the one who comes to it first" (al-Tirmidhi 1996). ${ }^{13}$ Accordingly, the patient who is on a ventilator is considered to have more 'right' to it than the patient who has not yet had it applied. Al-Sarīin judges it impermissible to withdraw therapy in this circumstance. Notably, this position may prove to be discriminatory against those who live further away from the hospital or who do not have means of transportation or who are disabled or infirm. As such it may raise more ethical questions than it resolves if it was the sole rationale (BMA 2020).

With respect to Scenario B, our view is that a policy that requires a patient be removed from a ventilator in order to apply it to another is not Islamically sanctioned. Rather Islamic law rejects definitive harming in the pursuit of a possible benefit. Further supporting this view are arguments based on precedence of place and time in the application of scarce resources.

12 Kitāb al-Istìdhān, Bāb lā yuqìm al-rajul al-rajul min majlisih.

13 Abwāb al-hajj, Bāb mā jā' anna Minā munākh man sabaq. 
Returning to the question of resource allocation [Scenario A], which patient(s) should be prioritized for ventilators and their ancillary treatments, hinges on specifying benefits at the patient and societal level. We have already discussed that ventilator support cannot be classified as one that has a certain or probable benefit for a specific patient. However, clinical data can predict which patients have a worse physiological state and thus have a reduced likelihood of benefitting from ventilator support. Thus, even though the likelihood of benefit is small, clinical decision rules that take into account patient characteristics, laboratory values and vital signs, can reliably and with dominant probability resolve which patient would have greater longevity or greater reduction in mortality (i.e. stand to benefit more) from a ventilator. Seeking to provide support to those that stand to benefit most is morally actionable and aligns with the ethico-legal arguments grounded in the construct of mașlaha. Hence a policy that incorporates predictions based on likelihood of benefit in order to allocate ventilators would be justified from an Islamic moral perspective.

Traditionally speaking, mașlaha-based ethico-legal arguments take two forms. The first form grounds arguments in a quasi-utilitarian fashion where scriptural dictates are not univocal. Scholars then identify the public, collective, and universal benefits of a certain action or policy, find scriptural and scientific evidences that legitimate such benefits, and then judge the policy which obtains the greatest benefit as Islamically-sanctioned (al-Būṭi 1973; Opwis 2005; Kamali 2003). The second form of argument links the notion of mașlaha directly to the agreed-upon overarching higher objectives of Islamic law (maqāṣid), namely the preservation of religion, life, wealth, intellect, and progeny/lineage, and maps out how a certain action or policy advantages or threatens these human interests (Kasule 2004; Ibrahim et al. 2019). Delving into the mechanics and details of these formulae is beyond this article's scope, yet is important to realize that mașlaha and maqāșid-based ethico-legal arguments move beyond individual patient concerns to consider societal benefit. As such when reasoning about which policies align with Islamic morality, such reasoning can be helpful.

With respect to COVID-19 related ventilator allocation, there are debates about prioritizing certain groups over others because they stand to benefit society in a greater fashion. For example, many bioethicists and policymakers have separated out 'essential' workers, and more prominently healthcare workers for priority, when it comes to ventilator allocation if all else is equal. They do so by arguing, in part, that when it comes to choosing between a nonhealthcare worker and a healthcare worker, saving the life of a healthcare worker may lead to preventing the death of others because the worker will benefit society through their professional duties after they convalesce. This 
argument is buttressed by others based on fact that healthcare workers bear greater risk of contracting the disease by treating CoviD-19 patients and this will risk-taking should be 'compensated' by prioritizing their need for scarce resources ( $\mathrm{Ng}$ et al. 2O2O; BMA 202O). Moving a bit further afield into considerations of social 'worth' of certain groups of individuals, some state authorities have argued that disabled individuals, non-citizens, or even the elderly should receive lower priority when resources are scarce. (SEMICYUC 2020). Although some might argue that the Islamic tradition can be used to justify the prioritization of healthcare workers over non-healthcare workers on account of all mașlaha, not all healthcare workers have the same community benefit to offer; a clinician is different from a technician and a dermatologist is different from a surgeon and so forth. If this argument is accepted, we suggest that Islamic morality would demand individualized prioritizations and not those based on class. Though prioritizing essential workers, or healthcare professionals, may be legitimated by recourse to a mașlaha-based argument, this assumes that the therapy is beneficial which is not true for all-comers. Hence there are holes in such an argument.

On the other hand, from an Islamic theological standpoint, one may argue that all considerations of social worth are problematic. The Qurān states unequivocally that God "has honored (karramnā) the children of Adam" (Q 17:70). Commentators note that this 'honoring' is inclusive of all members of the humankind (Kamali 2002). As such, all humans have the same intrinsic worth. Thus, as a general rule, even in times of scarcity, prioritizing humans based on their instrumental value to society threatens notions of a universal human karāma. A policy that does so is judged to be morally problematic.

Yet, Islamic legal precedent does allow for privileging individuals who have greater responsibilities over those with lesser responsibilities when doling out benefits. For example, individuals with larger families may be entitled to greater share of foodstuffs from the state foodbank than those with fewer on the basis of equity. Further the duty to prevent harm also supports such actions because if everyone received the same amount there would be a mismatch between need and supply in some families, and that harm must be deflected. A similar line of reasoning is used, partially, to permit the abortion of a fetus when the mother's life is at stake, since the mother has greater dependents her life can be prioritized (al-Mawsū'a al-Fiqhiyya al-Kuwaytiyya 1988-2006, 2:57) It seems then that either policy, privileging some individuals based on social consideration, or not privileging anybody, can be supported within the Islamic moral tradition.

Finally, a lottery system may be justified in Scenario A. The notion of drawing lots finds it roots in the practice of Prophet Jonah as well as Prophet 
Muhammad. In the former's case lots were cast to see who would jump off the ship during a storm as the seafarers believed God's wrath was upon the ship during a storm because of the misdeeds of one person. Prophet Jonah assented and got the proverbial 'short stick' and jumped ship. In the case of Prophet Muhammad, he would have his wives draw lots to see who would accompany him on excursions. In the first case drawing lots was to avert a harm from the group and in the second to procure benefit for a single individual. These instances suggest that a lottery system can be used in cases of moral ambiguity. Importantly such an action is not to be viewed as abdication of moral responsibility but rather trusting in God's providence. In the context of COVID-19 critical resource allocation, a lottery system by which patients are randomly allocated ventilators when all else is equal is Islamically-justifiable (al-Sarīī 2020; BinṬāhir 2020).

So, what would be Islamically-sanctioned justifiable policy rubric by which to allocate mechanical ventilation and associated therapies to patients in times of COVID-19 related scarcity? The preceding discussion suggests Islamic morality would sanction crisis standards of care and policies with the following components. First, they should utilize clinical data to judge who stands most to benefit from the application of a ventilator. Those that stand to have the greatest prospect of benefit, i.e. have their life saved, should be prioritized. It is important to recognize that the majority of COVID-19 patients who require respiratory support by mechanical ventilation will not survive, so using clinical data here to guide the application of a scare resource with marginal utility is apropos. Such clinical algorithms are considered to reach the grade of dominant probability (ghalabat al-zann) in Islamic legal lexicon and can be utilized.

If the clinical benefit is equivalent between two patients then a lottery system can be used to choose one over the other. Prioritizing individuals based on social worth is a slippery slope, although one might justify prioritizing essential workers and healthcare workers due to the risks they bear and the societal benefit they bring. Giving priority to those who come first can also find support within scripture.

In cases where a ventilator must be removed from one patient to apply it to another, we find such an action objectionable from an Islamic point of view. Since prioritizing those who come first has scriptural grounds, withdrawing a ventilator to serve another patient is morally suspect. Moreover, there is the moral imperative of not perpetrating harm, and withdrawing a ventilator would harm a patient in the process of trying to procure a benefit for another party.

One nuance to consider is that withdrawing a ventilator and associated therapies from a patient is justified because the treatment is doubtful and 
carries credible harms. A clinician may withdraw such therapies from a patient to honor patient (or surrogate decision-maker) choice. In so doing a ventilator may become available. However, the action of withdrawing a ventilator and then using it for another patient must separate in time and intentionality. When withdrawing therapy is necessary to benefit another patient, the action would be morally illicit.

Finally, we believe that any state policy regarding resource allocation should allow for claims of conscience. Muslims who do not feel comfortable following the state policies enacted, or with the Islamic guidance they obtain, should be allowed to recuse themselves from enacting such policies. We believe claims of conscience are of critical importance in civic society and core to the Islamic tradition.

\section{Moral Conversations: Responsibilities \& Recourses in Healthcare Delivery}

Our foregoing Islamic bioethical analysis acknowledges that healthcare delivery occurs in web of interconnected contracts, be they social, legal or moral, and that all these must be accounted for when in bioethical deliberation. Indeed, every action taken by a patient or provider in the context of a healthcare encounter is morally laden, as is every health policy enacted by a state or local authority. As individuals we cannot absolve ourselves of the ethical conundrums presented by the choices we make. Rather the job of ethicists, be religious authorities or secular ones, is to provide a moral framework for justifying some actions over others and in so doing engender a more ethical world. Our analysis thus offers ethical justification, from an Islamic perspective, for certain choices and actions over others in the context of CoviD-19 resource scarcity and decisions about life-sustaining mechanical ventilation. In addition to adding to the literature on CoviD-19 ethics our work adds to academic bioethical discussions and has implications for the institution of medical fatwā-making.

With respect to the academic bioethics discourses, the preceding discussion adds to the literature on end-of-life care ethical decision-making and religion. There have been many empirical studies suggesting that religious adherents are more likely to partake of futile care and intensive therapies near the endof-life than less religious patients (Shinall and Guillamondegui 2015; Balboni et al. 2013). These observations suggest that religious ethics demands that life be preserved 'at all costs.' Our work suggests that, from an Islamic perspective, the overarching objective of preserving life is not unbounded, and that a 
nuanced reading of scriptural and legal evidence suggests that this objective must be balanced by duties to deflect harm from non-efficacious therapies. Further empirical study is needed to see how religious dictates are lived out in the lives of Muslim patients and families.

Our discussion also finds that the Islamic tradition affirms informed decisionmaking and acknowledges moral ambiguity near the end-of-life. Indeed, neither the patient nor the clinician is obligated to apply mechanical ventilation, which assuredly is life-sustaining but may not be exactly life-saving. ${ }^{14}$ Rather the tradition allows both to 'opt out'; the patient forgoing intubation and the clinician taking recourse to conscience clauses. With respect to current bioethics discussions over crisis standards of care and resource allocation, our analysis finds the tradition to reject intrinsic worth rubrics that may exacerbate racism and threaten human dignity. Instrumental value considerations when it comes to prioritizing some patients over others appear to be morally perilous, and a slippery slope towards denying intrinsic dignity and harming the socially underprivileged. Rather, Islamic moral choices demand we recognize God's wisdom and control over all affairs and enact policies that are equitable.

Finally, our work bears significance for the field of Islamic bioethical deliberation and the institution of medical fatw $\bar{a}$-making. We must underscore that our bioethics guidance is general and must be worked into particular contexts, and is some ways is akin to a $\mathrm{hukm}$ and not a fatwa, or to general principles that must be specified to individual cases. Resolving an 'Islamic' position on pressing bioethical issues, as those noted above, usually falls to the mufti or Islamic jurisconsult. They are consulted by patients, providers, and policymakers who see fatwa as a tool by which actions can be aligned with Islamic bioethics. This is, however, not without a number of philosophical and practical problems, given the many contentions around what Islamic bioethics represents, and the limitations evident in some fatāwa (Padela 2013). Despite this, one cannot deny the labelling authority given to muftis in modern times by Muslims, and by extension the weight that such fatāwa carry (Padela 2012).

The CoviD-19 pandemic, and specifically the topics of resource allocation, has highlighted limitations in fatwa $\bar{a}$-crafting. As noted above, some of these relate to Islamic legists not having the knowledge and tools by which to fully conceptualise the societal contexts and understand the ramifications of

14 By life-sustaining we mean that mechanical ventilation can allow for appearances of life to be maintained, e.g. breathing, almost indefinitely. This is different from life-saving treatment by which we mean a curative or restorative application of mechanical ventilation such that an individual will not need to be on a ventilator for the rest of their life. The conceptual lines are not fully sharp in the bioethics literature, yet are used in practice (see Watne 1995, 42-46). 
clinical decisions. This in turns speaks to the broader issue of how biomedical and societal data is channelled into ethico-legal deliberation.

Consequently, it is worthwhile taking a broader view of fatwā-crafting, which can be construed as the art of harmonizing religion and reality. Though couched in legal language, the muft is seeking to answer the question 'what is the good in this situation?' To do so, the muftì must marshal all resources at his/ her disposal - both religious, like scripture and legal precedent, and 'secular,' such as biomedical and social scientific data, as well as more abstract concepts such as quality of life - to correctly ascertain the intricacies of the present situation and the consequences of his/her judgment. With these resources and understandings front of mind, he/she must fashion a fatwa that is coherent and defensible in terms of the scholarly tradition and practicable in the present moment.

From a knowledge-based perspective, all too often, those that render medical fatwa (both individuals and institutions) have considerable skill in navigating religious texts and evidences, but lack similar competence with respect to the biomedical and social sciences. In some cases, the mufti will be all-tooaware of this deficiency, and in others be oblivious. Herein we have striven to show how clinical data and social realities must inform Islamic bioethical judgements, and that these must be read with a critical eye. Not doing so renders moral judgements incomplete and impractical. Cultivating trust and cooperation between specialists in Islamic law and biomedical and social sciences is thus critical to the future of medical fatw $\bar{a}$-making.

There are also, however, deeper tensions to resolve. At the surface-level, the mechanism of rendering fatwa $\bar{a}$ seems relatively straightforward: accurately conceptualize the situation, delve into the corpus for an appropriate paradigm case, correctly apply the inferential mechanisms including, where relevant but not primarily the qawāid fiqhiyya and maqāșid al-sharīa (Bin Bayya 2018; Usmani 2011). Beyond this however there are additional complexities, some of which operate subconsciously within the mind of the mufti.

At a psychological level, the mufti is often aware of the need to remain within - and to be seen to remain within - the aegis of his school, sub-school or tradition. The maintaining of credibility among one's peers is as important to a mufti as to any other professional, and stepping outside the safety of a millennium of precedent can be a discomfiting experience, requiring extensive explanation for why the step is being taken. Thus, fatwa tend to heavily cite precedent and legal school positions. The muft t may also be subconsciously informed by a range of unexamined assumptions, from grievances about power-dynamics (e.g.: 'people should listen to their religious leaders, but they 
don't') to concerns about prevailing discourse (e.g.: 'group x wishes to maintain their authority by controlling information flow, and I should resist'). These psychological pulls may also reveal themselves in a reticence to seek out the biomedical and social scientific expertise needed to render nuanced bioethical judgements. This may be because they believe such data would either be beyond their understanding, or that harms and benefits should be clear to the layperson otherwise it is not a credible truth claim.

The mufti also has to navigate tensions between a number of meta-ethical approaches, from the 'deontological voluntarism' (the good is what God commands, or what can be inferred from it) to a 'teleological utilitarianism' (the good is what maximizes benefit and/or minimizes harm), and of 'intuitionism' (the good is what gives peace to the heart) (Brown 1999). Of these, utilitarian approaches play an outsize role, because the scholarly tradition is equivocal on modern questions, capable of being read in different ways and supporting different positions.

Combined, these three factors - a lack of expertise, psychological pulls and meta-ethical presumptions - can lead to three possible outcomes:

(1) the mufti is oblivious to the underlying factors, thus issuing rulings that reflect superficial understandings of biomedicine, unconsidered biases and unexamined meta-ethical positions. Despite being dressed up in the language of independent legal reasoning, these can sometimes be either needlessly reactionary or excessively rigid, rendering the fatwa impracticable or incomprehensible to the end-user.

(2) The mufti is vaguely aware of the factors but does not know what to do about them. This case leads to issuing a ruling on the basis of (i) pure utilitarianism where the benefits of action are privileged and defined on the basis of what medical experts say. Or (ii) yielding to an ill-defined notion of necessity (darüra) where the action would be prohibited by Islam but biomedical and/or social contexts allow it to be permitted. Both of these render the muft $\vec{s}$ role as almost wholly superfluous to the enterprise of ethical and moral assessment.

(3) The mufti is acutely aware of his/her own sub-conscious biases, the metaethical positions being adopted, and gaps in their understanding of the biomedical facts. As such he/she works to minimize biases by considering alternative views, reflects on his/her meta-ethical positions and engages with scholars holding different positions to understand their rationale and thinking, and partners with biomedical and social scientific experts who can critically appraise their fields. By doing so medical fatwā-making becomes an iterative process and a collective enterprise. 
The first outcome is least desired because it does not provide actionable guidance. The second approach, a surface-level analysis by recourse to mașlaḥa and darüra-based arguments, is ill-suited to multilevel analysis. What is beneficial or harmful must be considered in light of the multiple moral agents involved in healthcare, and notions of benefit and harm must be conceptualized in light of the presenting situation. Indeed, when the problem-space is not correctly understood the bioethical guidance is misaligned. The third option, we believe, must be taken. Grasping all the facts is critical to making moral judgements, and further argue that being aware of the psychological dimensions of fatwa $\bar{a}$-crafting is vital to minimise the effects of subconscious bias. Additionally, awareness of the underlying meta-ethical considerations allows for interrogating the spirit and purpose of the fatwa , elevating it from a mere mechanical exercise to a genuine ethical contribution to the clinical decision-making process.

In summary, we recognize that in engaging with biomedical realities and their ethical problem-space, the mufti is often at a disadvantage. He/she may not be able to read, interpret and interrogate the clinical evidence. He/she may lack the tools required to analyse benefits and harms from multiple vantagepoints and on the societal register. Beyond this he/she may have subconscious biases and meta-ethical assumptions that hamstring moral assessment. Consequently, we call for Islamic legists to deliberate together with those from different schools and mindsets, and with scholars of biomedicine and the social sciences. Additionally, we call for using multi-level analytic frameworks and critically appraising the truth claims of biomedicine and scripture in pursuing Islamic bioethical judgements.

Finally, in addition to working with others, it is important to upskill the mufti class with such epistemic and cognitive tools that they might not merely accept what they are told about medicine and society, but be able to critically analyse these domains. This would allow the mufti to determine where on the spectrum of certainty a particular view lies on the basis of interrogating the data rather than mere intuition. It also would allow a more granular exploration of concepts such as necessity, need, hardship, fear of harm and customary norms, none of which are laid out in much detail in the legal manuals.

Our foregoing exploration of Islamic ethico-legal perspectives on patient options, clinical decision-making, and resource allocation with respect to ventilators in the context of the CoviD-19 pandemic has demonstrated the urgent need for close partnerships between scholars of the texts and of the contexts. And it highlights the need for detailed inspections of the art and practice, rather than the science, of fatwa $\bar{a}$-making. 


\section{Bibliography}

Abū Dāwūd. 1998. Sunan Ab̄̄ Dāwūd, edited by Muḥammad 'Awwāma. Beirut: Mu'assasat al-Rayyān.

Ahmad, Wahaj D., Ahmed El-Kadi, and Bashir Ahmed Zikria. 1988. "Oath of a Muslim Physician." Journal of the Islamic Medical Association of North America 2O(1): 11-14. doi:10.5915/20-1-1305o.

Ahmed, Kamaluddin. Forthcoming 2021. "Science in the Framework of Islamic Legal Epistemology: An Exploratory Essay." In Islam and Biomedicine, edited by Aasim Padela and Afifi Akiti, 325-345. Dordrecht: Springer.

Ali, Mansur. 2019. "Our Bodies Belong to God, So What?: God's Ownership vs. Human Rights in the Muslim Organ Transplantation Debate." Journal of Arabic and Islamic Studies 19: 57-80.

Ali, Mansur and Usman Maravia. 2020. "Seven Faces of a Fatwa: Organ Transplantation and Islam." Religions 11(99). doi:10.339o/rel11020099.

American Nurses Association. 2020. Crisis Standard of Care: COVID-19 Pandemic. Silver Spring, MD: Center for Health Policy, Columbia University School of Nursing. AMJA Resident Fatwa Committee. 2020a. “COVID-19 Related Fatawa." Accessed July 202O. www.amjaonline.org/COVID-19-related--fatawa.

AMJA Resident Fatwa Committee. 2020b. "Scarcity of Medical Resources and Rationing During the COVID-19 Pandemic." Accessed July 2020. www.amjaonline.org/ fatwa/en/87747/scarcity-of-medical-resources-and-rationing-during-the-COVID -19-pandemic.

AmJA Resident Fatwa Committee. 2020c. "The Ruling on Getting the COVID-19 (Coronavirus) Vaccine." Accessed December 2020. www.amjaonline.org/fatwa/ en/87763/the-ruling-on-getting-the-covid-19-coronavirus-vaccine.

Anjum, Ovamir. 2007. "Islam as a Discursive Tradition:Talal Asad and his Interlocutors." Comparative Studies of South Asia, Africa and the Middle East 27(3): 656-672.

al-'Anqāwī, Ṭāriq b. Ṭalāl. 2020. "Ru'ya Shar'iyya Ḥawl al-Tazāḥum 'alā al-Mawārid al-Ṭibbbiyya fì Zaman Tafashshī Fīrūs Kūrūnā al-Mustajadd.” Accessed July 2020. https://atharah.com/crowding-for-medical-resources/.

Auld, Sara, Mark Caridi-Scheible, James M. Blum, Chad J. Robichaux, Colleen S. Kraft, Jesse T. Jacob, Craig S. Jabaley, David Carpenter, Roberta Kaplow, and Alfonso C. Hernandez. 202O. "ICU and Ventilator Mortality among Critically ill Adults with COVID-19." MedRxiv 48(9): e799-e804. doi:10.1097/CCM.oooooooooooo4457.

Balboni, Tracy A., Michael Balboni, Andrea C. Enzinger, Kathleen Gallivan, M. Elizabeth Paulk, Alexi Wright, Karen Steinhauser, Tyler J. VanderWeele, and Holly G. Prigerson. 2013. "Provision of Spiritual Support to Patients with Advanced Cancer by Religious Communities and Associations with Medical Care at the End of Life." JAMA Internal Medicine 173(12): 1109-1117. 
al-Bārr, Muḥammad 'Alī. 2005. “Al-Idhn bi-l-'Amal al-Ṭibbī." Majallat al-Majma'al-Fiqhī al-Islāmī 10: $255^{-78 .}$

al-Bārr, Muḥammad 'Alī. 2007. "Seeking Remedy, Abstaining from Therapy and Resuscitation: An Islamic Perspective." Saudi Journal of Kidney Diseases and Transplantation 18(4): 629 .

al-Bārr, Muhammad 'Alī, and Ḥassān Shamsī-Bāshā. 2004. Mas'ūliyyat al-Ṭabīb bayn al-Fiqh wa-l-Qānūn. Damascus: Dār al-Qalam.

B BSI. 2020a. "Declarations." Accessed July 2020. http://www.bbsi.org.uk/declarations/. B BSI. 2O2Ob. "A Matter of Life and Death:The Ethics of Resource Distribution, Intensive

Care and Treatment Choices in the Light of COVID-19 Pandemic." Accessed July 2020. www.bbsi.org.uk/amatter-oflifeanddeath/.

BBSI. 2020c. "Top Ten Questions Imams \& Scholars Get Asked About Vaccines." Accessed December 2020. www.bbsi.org.uk/top-ten-questions-imams-scholars-get -asked-about-vaccines/.

Bin Bayya, 'Abd Allāh. 2018. Șinā'at al-Fatāwā wa-Fiqh al-Aqalliyāt. Abu Dhabi: Al-Muwațța' Centre.

BinṬāhir, 'Abd Allāh. 202o. "Man Huwa al-Awlā bi-l-'Ilāj cinda Kathrat al-Marḍā wa-Qillat Wasảil al-'Ilāj bi-Sabab Kūrūnā?” Accessed June 2020. www.facebook .com/1475787426061599/posts/226539o893767911/.

BMA. 2020. "COVID-19 - Ethical issues: A guidance note." Accessed June 2020. www .bma.org.uk/advice-and-support/COVID-19/ethics/COVID-19-ethical-issues.

Brewster, David J., Nicholas C. Chrimes, Thy BT Do, Kirstin Fraser, Chris J. Groombridge, Andy Higgs, Matthew J. Humar, Timothy J. Leeuwenburg, Steven McGloughlin, and Fiona G. Newman. 2020. "Consensus Statement: Safe Airway Society Principles of Airway Management and Tracheal Intubation Specific to the COVID-19 Adult Patient Group." Medical Journal of Australia 212(10): 472-481. doi: 10.5694/ mja2.50598.

Brown, Daniel. 1999. "Islamic Ethics in Comparative Perspective." The Muslim World 89(2): 181-192.

Brown III, Calvin A., Aaron E. Bair, Daniel J. Pallin, Ron M. Walls, and NEAR III Investigators. 2015. "Techniques, Success, and Adverse Events of Emergency Department Adult Intubations." Annals of Emergency Medicine 65(4): 363-370.

Buchanan, Allen. 1978. "Medical Paternalism." Philosophy \& Public Affairs 7(4):370-39o. al-Bukhārī, 'Alā al-Dīn 'Abd Al-'Azīz. 1997. Kashf al-Asrār 'an Ușūl Fakhr al-Islām al-Bazdawī, vol. 4. Beirut: Dār al-Kutub al-'Ilmiyya.

al-Bukhārī, Muhammad b. Ismāîil. [n.d.]. Al-Jāmi al-Ṣaḥ̄h, edited by Muhammad Zuhayr b. Nāșir al-Nāșir. [n.p.]: Dār Ṭawq al-Najāt.

al-Būṭī, Muḥammad Saīi Ramaḍān. 1973. Dawābiṭal-Maṣlaḥa fí al-Sharîa al-Islāmìyya. Beirut: Mu’assassat al-Risāla. 
Butt, Mohammed Zubair. 2019. "Organ Donation and Transplantation in Islam: An Opinion." Accessed June 2019. https://nhsbtdbe.blob.core.windows.net/umbraco -assets-corp/163oo/organ-donation-fatwa.pdf.

Center for Systems Science and Engineering. 2020. "Coronavirus Resource Centre.John Hopkins University \& Medicine.” Accessed July 2020. https://coronavirus.jhu.edu/ map.html.

Chu, Derek K., Elie A. Akl, Stephanie Duda, Karla Solo, Sally Yaacoub, Holger J. Schünemann, Amena El-harakeh, Antonio Bognanni, Tamara Lotfi, and Mark Loeb. 2020. "Physical Distancing, Face Masks, and Eye Protection to Prevent Person-toPerson Transmission of SARS-CoV-2 and COVID-19: A Systematic Review and Meta-Analysis." The Lancet 395. doi:10.1016/So14o-6736(20)31142-9.

Darul Ifta, Darul Qasim. 2020. "Fatwā on COVID Vaccines." Accessed December 2020. https://darulqasim.org/fatwa-on-covid-vaccines/.

ECFR. 202O. "Al-Mustajaddāt al-Fiqhiyya li-Nāzilat Fīrūs Kūrūnā COVID-19." Accessed June 2020. https://tinyurl.com/y2czvhww. The European Council for Fatwa and Research.

El Fadl, Khaled Abou. 2003. "Islam and the Challenge of Democratic Commitment." Fordham International Law Journal 27: 4.

Elkins, Amber D., and Dennis M. Gorman. 2014. Systems Theory in Public Health. Oxford: Oxford University Press.

Geertz, Clifford. 1971. Islam Observed: Religious Development in Morocco and Indonesia. Chicago: University of Chicago Press.

Geleris, Joshua, Yifei Sun, Jonathan Platt, Jason Zucker, Matthew Baldwin, George Hripcsak, Angelena Labella, Daniel K. Manson, Christine Kubin, and R. Graham Barr. 2020. "Observational Study of Hydroxychloroquine in Hospitalized Patients with COVID-19." New England Journal of Medicine 382 (25):2411-2418. doi: 10.1056/ NEJMoa2O12410.

Ghaly, Mohammed. 2010. Islam and Disability: Perspectives in Theology and Jurisprudence. Abingdon: Routledge.

Ghaly, Mohammed. 2014. "Pre-modern Islamic Medical Ethics and Graeco-IslamicJewish Embryology." Bioethics 28(2): 49-58.

al-Ghazālī, Abū Haāmid. 1993. Al-Mustaşfā, edited Muḥammad 'Abd al-Salām 'Abd al-Shāfi. Beirut: Dār al-Kutub al-'Ilmiyya.

al-Ghazālī, Abū Ḥāmid. 1993. Qanūn al-Ta’wūl, edited by Muḥammad Zāhid al-Kawtharī. Cairo: Maktabat al-Azhariyya lil-Turāth.

al-Ghazālī, Abū Hāmid. 20oo. The Incoherence of the Philosophers: A parallel English-Arabic tekst, translated, introduced and annotated by Michael E. Marmura. Provo, Utah: Brigham University Press.

Goyal, Parag, Justin J. Choi, Laura C. Pinheiro, Edward J. Schenck, Ruijun Chen, Assem Jabri, Michael J. Satlin, Thomas R. Campion Jr, Musarrat Nahid, and Joanna B. Ringel. 
2020. "Clinical Characteristics of COVID-19 in New York City." New England Journal of Medicine 382(24): 2372-2374. doi: 10.1056/NEJMc2010419.

Hamdy, S. 2013. "Not Quite Dead:Why Egyptian Doctors Refuse the Diagnosis of Death by Neurological Criteria." Theoretical Medicine and Bioethics 34: 147-16o.

Häyry, Heta. 2002. The Limits of Medical Paternalism. London and New York: Routledge. Ibn Māja, Muḥammad b. Yazīd. 1998. Sunan Ibn Māja, edited by Bashshār 'Awwād Ma'rūf. Beirut: Dār al-j̄̄l.

Ibn Nujaym, Zayn al-Dīn. 1999. Al-Ashbāh wa-l-Nazā̄ir, edited by Zakariyyā 'Umayrāt. Beirut: Dār al-Kutub al-'Ilmiyya.

Ibn Rushd. 1997. Faṣl al-Maqāl fì Taqrīr mā bayn al-Sharīa wa-l-Hikma min al-Ițtișāl. Beirut: Markaz Dirāsat al-Waḥda al-'Arabiyya.

Ibn Taymiyya. 1991. Dar' Ta āruḍ al-'Aqlwa-l-Naql. Riyadh: Jāmi'at al-Imām Muhammad b. Sacūd al-Islāmiyya.

Ibrahim, Abdul Halim, Noor Naemah Abdul Rahman, Shaikh Mohd Saifuddeen, and Madiha Baharuddin. 2019. "Maqasid al-Shariah based Islamic Bioethics: A Comprehensive Approach." Journal of Bioethical Inquiry 16(3): 333-345.

ImANA Ethics Committee. 2020. "Addressing COVID-19." Accessed June 2020. https:// imana.org/COVID-19/.

Institute for Health Metrics and Evaluation. 2020. "COVID-19 Projections." University of Washington Accessed July 2020. https://covid19.healthdata.org/united -states-of-america.

Kamali, Mohammad Hashim. 2002. The Dignity of Man: An Islamic Perspective. Cambridge: Islamic Texts Society.

Kamali, Mohammad Hashim. 2003. Principles of Islamic Jurisprudence. Cambridge: Islamic Texts Society.

Kasule, Omar Hasan. 2004. "Medical Ethics from Maqasid Al Shari'at." Arab Journal of Psychiatry 15(2): 75 .

Kenney, Jeffrey T., and Ebrahim Moosa, eds. 2014. Islam in the Modern World. London and New York: Routledge.

al-Khațīb, Mu'tazz. 2020. "Kūrūnā wa-Mushkilāt al-Fatwā bi-Sha'n al-Ahaqq bi-l'Ilāj 'inda al-Tazāḥum." Aljazeera 2020. Accessed July 2020. https://tinyurl.com/ ycq86eka.

Koulenti, D., E. Tsigou, and J. Rello. 2017. "Nosocomial Pneumonia in 27 ICUs in Europe: Perspectives from the EU-VAP/CAP Study." European Journal of Clinical Microbiology \& Infectious Diseases 36(11): 1999-2006.

Macon-Cooney, Benedict, Ryan Wain, Daniel Sleat, Ruti Winterstein, and Kasra Aarabi. 2020. Learning to Live Alongside COVID-19. Tony Blair Institute for Global Change (Online). https://institute.global/policy/learning-live-alongside-COVID-19.

Magagnoli, Joseph, Siddharth Narendran, Felipe Pereira, Tammy H. Cummings, James W. Hardin, S. Scott Sutton, and Jayakrishna Ambati. 2020. "Outcomes of 
Hydroxychloroquine Usage in United States Veterans Hospitalized with COVID-19." Med 1: 114-127. doi:10.1016/j.medj.2020.06.oo1.

Manley, MT. 1978. "Incidence, Contributory Factors and Costs of Pressure Sores." South African Medical Journal 53(6): 217-222.

Maravia, Usman. 2020. "Rationale for Suspending Friday Prayers, Funerary Rites, and Fasting Ramadan during COVID-19: An Analysis of the Fatawa Related to the Coronavirus." Journal of the British Islamic Medical Association 4: 10-15.

Mareiniss, Darren P. 2020. "The Impending Storm: COVID-19, Pandemics and our Overwhelmed Emergency Departments." The American Journal of Emergency Medicine 38(6): 1293-1294. doi: 10.1016/j.ajem.2020.03.033.

Marini, John J., and Luciano Gattinoni. 2020. "Management of COVID-19 Respiratory Distress." JAMA 323(22): 2329-2330. doi: 10.1001/jama.2020.6825.

al-Mawsū'a al-Fiqhiyya al-Kuwaytiyya. 1988-2006. Kuwait: Ministry of Islamic Affairs Kuwait.

Ñamendys-Silva, Silvio A. 2020. "Respiratory Support for Patients with COVID-19 Infection." Lancet Respiratory Medicine 8(4): e18. doi: 10.1016/S2213-26oo(20)30110-7. Ng, Kangqi, Beng Hoong Poon, Troy Hai Kiat Puar, Jessica Li Shan Quah, Wann Jia Loh, Yu Jun Wong, Thean Yen Tan, and Jagadesan Raghuram. 2020. "COVID-19 and the Risk to Health Care Workers: A Case Report." Annals of Internal Medicine 172(11): 766-767. doi: 10.7326/L2O-0175.

Nuffield Council on Bioethics. 2020. "Fair and Equitable Access to COVID-19 Treatments and Vaccines." Accessed July 2020. www.nuffieldbioethics.org, Nuffield Council on Bioethics.

OIC-IIFA. 2000. Resolutions and Recommendations of the Council of the Islamic Fiqh Academy 1985-2000. Jedda: Islamic Research and Training Institute Islamic Development Bank.

Opwis, Felicitas. 2005. "Mașlaḥa in Contemporary Islamic Legal Theory." Islamic Law and Society 12(2): 182-223.

Padela, Aasim I. 2013. "Islamic Bioethics: Between Sacred Law, Lived Experiences, and State Authority." Theoretical Medicine and Bioethics 34(2): 65-80.

Padela, Aasim, and Omar Qureshi. 2017. "Islamic Perspectives on Clinical Intervention near the End-of-Life: We Can but Must We?" Medicine, Health Care and Philosophy 20(4): 545-559.

Padela, Aasim, and Afshan Mohiuddin. 2015. "Ethical Obligations and Clinical Goals in End-of-Life Care: Deriving a Quality-of-Life Construct Based on the Islamic Concept of Accountability before God (taklïf)." The American Journal of Bioethics 15(1):3-13.

Padela, Aasim I., Hasan Shanawani, and Ahsan Arozullah. 2012. "Using Fatawa within Islamic and Muslim Bioethical Discourse: The Role of Doctrinal and Theological Considerations - A Case Study of Surrogate Motherhood." In Islam and Bioethics, edited by Berna Arda and Vardit Rispler-Chaim, 151-167. Ankara: Ankara University. 
al-Qaradāghī, 'Alī Muḥyī al-Dīn and 'Alī Yūsuf Muḥammadī. 20o6. Fiqh al-Qaḍāyā al-Ṭibbiyya al-Mu'āṣira. Beirut: Dār al-Bashāiir al-Islāmiyya.

al-Qaradāgh̄̄, 'Ārif. 2011. Qaḍāyā Fiqhiyya fì Naql al-A'ḍā’ al-Bashariyya. Kuala Lumpur: IIUM Press.

Qureshi, Omar, and Aasim I. Padela. 2016. "When Must a Patient Seek Healthcare? Bringing the Perspectives of Islamic Jurists and Clinicians into Dialogue." Zygon 51(3): 592-625.

Raḥmānī, Khālid Sayf Allāh. 2010. Jadīd Fiqhī Masā̉il, vol. 5. Karachi: Zamzam Publishers.

Richardson, Safiya, Jamie S. Hirsch, Mangala Narasimhan, James M. Crawford, Thomas McGinn, Karina W. Davidson, Douglas P. Barnaby, Lance B. Becker, John D. Chelico, and Stuart L. Cohen. 2020. "Presenting Characteristics, Comorbidities, and Outcomes among 5700 Patients Hospitalized with COVID-19 in the New York City Area." JAMA 323(20): 2052-2059. doi: 10.1001/jama.2020.6775. Erratum in: JAMA. 2020 May 26;323(20):2098.

al-Ṣabrī, Mas'ūd. 202o. Fatāwāa al-'Ulamāa ḥawl Fìrūs Kūrūnā. Cairo: Dār al-Bashīr.

Saleh, Mona, and Mohammed Ghaly. 2020. "Islamic Ethical Perspectives on the Allocation of Limited Critical Care Resources During the COVID-19 Pandemic." Journal of British Islamic Medical Association 4(2): 3-7.

al-Sarīī, Mawlūd. 2020. "Tazāḥum al-Ḥuqūq 'Inda Qillat al-Mawārid al-Ṭibbiyya." Madrasat Tankarit al-'Atīqa. Accessed June 2020. www.youtube.com/watch?v=eqy_ mTX_z8c\&feature=youtu.be.

SEMICYUC. 2020. "Recomendaciones Éticas Para La Toma De Decisiones En La Situación Excepcional De Crisis Por Pandemia COVID-19 En Las Unidades De Cuidados Intensivo." Sociedad Española De Medicina Intensiva, Crítica Y Unidades Coronarias. Accessed July 2020. https://semicyuc.org/wp-content/uploads/ 2020/03/\%C3\%8gtica_SEMICYUC-COVID-19.pdf.

Shabbir, Yusuf. 2020. "Is the Pfizer BioNTech Covid-19 Vaccine Halal?" Islamic Portal. Accessed December 2020. https://islamicportal.co.uk/is-the-pfzier-biontech-covid -19-vaccine-halal/.

Shinall, Myrick C., and Oscar D. Guillamondegui. 2015. "Effect of Religion on End-of-Life Care among Trauma Patients." Journal of Religion and Health 54(3): 977-983.

al-Shinqīị̄i, Muḥammad b. Muḥammad al-Mukhtār. 1994. Aḥkām al-Jirāḥa al-Ṭibbiyya. Jeddah: Maktabat al-Sahāba.

Stearns, Justin. 2008. "Enduring the Plague: Ethical Behaviour in the Fatwas of a Fourteenth-Century Mufti and Theologian." In Muslim Medical Ethics: From Theory to Practice, edited by Jonathan Brockopp and Thomas Eich, 38-54. Columbia, SC: The University of South Carolina Press.

Stodolsky, M. V. Y. and M. A. Kholwadia. 2021. "A Jurisprudential (Ușūlı̀) Framework for Cooperation between Muslim Jurists and Physicians and Its Application to the 
Determination of Death." In Medicine and Shariah: A Dialogue in Islamic Bioethics, edited by A. I. Padela. Notre Dame: University of Notre Dame Press.

al-Tirmidhī, Muhammad b. 'Īsā. 1996. Sunan al-Tirmidhī, edited by Bashshār 'Awwād Ma'rūf. Beirut: Dār al-Maghrib al-Islāmī.

Tobin, Martin J. 2020. "Basing Respiratory Management of COVID-19 on Physiological Principles." American Journal of Respiratory and Critical Care Medicine 201(11): 13191320. doi: 10.1164/rccm.202004-1076ED.

al-Uthmānī, Muḥammad Taqī. 2011. Ușūl al-Iftă’ wa-Ādābuh. Karachi: Maktabat Ma'ārif al-Qur’ān.

Viswanathan, Kristin, Dan Hanfling, Bruce M. Altevogt, and Lawrence O. Gostin. 2012. Crisis Standards of Care: A Systems Framework for Catastrophic Disaster Response. Washington DC: National Academies Press. doi:10.17226/13351.

Watne, Kara. 1995. "Distinguishing between Life-Saving and Life-Sustaining Treatments: When the Physician and Spouse Disagree." Dimensions of Critical Care Nursing 14(1): $42-46$.

White, Douglas B., and Bernard Lo. 2020. "A Framework for Rationing Ventilators and Critical Care Beds during the COVID-19 Pandemic." JAMA 323(18): 1773-1774. doi:10.1001/jama.2020.5046.

Wifaqul Ulama. 2020. "What is the Islamic Ruling for Pfizer/BioNTech COVID-19 Vaccine and is it Halāl?" Accessed December 2020. www.wifaqululama.co.uk/ wifaq-pfizer/.

$\mathrm{Wu}$, Zunyou, and Jennifer M. McGoogan. 2020. "Characteristics of and Important Lessons from the Coronavirus Disease 2019 (COVID-19) Outbreak in China: Summary of a Report of 72314 Cases from the Chinese Center for Disease Control and Prevention." JAMA 323(13): 1239-1242. doi:10.1001/jama.2020.2648.

Yacoub, Ahmed Abdel Aziz. 2001. The Fiqh of Medicine: Responses in Islamic Jurisprudence to Development in Medical Science. London: Ta-Ha Publishers Ltd.

Yao, Wenlong, Tingting Wang, Bailing Jiang, Feng Gao, Li Wang, Hongbo Zheng, Weimin Xiao, Li Xu, Shanglong Yao, and Wei Mei. 2020. "Emergency Tracheal Intubation in 202 Patients with COVID-19 in Wuhan, China: Lessons Learnt and International Expert Recommendations." British Journal of Anaesthesia 125(1): e28e37. doi: 10.1016/j.bja.2020.03.026.

Yong, Phui S. Au and Xuanxuan Chen. 2020. "Reducing Droplet Spread During Airway Manipulation: Lessons from the COVID-19 Pandemic in Singapore." British Journal of Anaesthesia 125(1): e176-e178. doi: 10.1016/j.bja.2020.04.007.

Yusuf, Asim. 2017. Shedding Light on the Dawn: On the Determination of Prayer and Fasting Times at High Latitudes. Nur al-Habib Productions.

Zangrillo, Alberto, Luigi Beretta, Anna Mara Scandroglio, Giacomo Monti, Evgeny Fominskiy, Sergio Colombo, Federica Morselli, Alessandro Belletti, Paolo Silvani, and Martina Crivellari. 2020. "Characteristics, Treatment, Outcomes and Cause of 
Death of Invasively Ventilated Patients with COVID-19 ARDS in Milan, Italy." Crit Care Resuscitation, Apr 23; [Advance Online].

Zhou, Fei, Ting Yu, Ronghui Du, Guohui Fan, Ying Liu, Zhibo Liu, Jie Xiang, Yeming Wang, Bin Song, Xiaoying Gu, Lulu Guan, Yuan Wei, Hui Li, Xudong Wu, Jiuyang Xu, Shengjin Tu, Yi Zhang, and Hua Chen. 2020. "Clinical Course and Risk Factors for Mortality of Adult Inpatients with COVID-119 in Wuhan, China: A Retrospective Cohort Study." Lancet 395: 1054-1062. doi: 10.1016/So140-6736(20)30566-3.

Zulfiqar, Adnan. 2020. "Mapping COVID-19 Fatwās." Islamic Law Blog, Sharia Source at Harvard Law School. Accessed July 2020. https:/islamiclaw.blog/2020/05/O4/ mapping-COVID-19-fatwas/. 